поставок, позволяет госструктурам сберечь ресурсы, а также не выполнять те действия, которые не являются нужными.

$$
* * *
$$

1. Информационно-аналитические системы и технологии в государственном и муниципальном управлении: Учебное пособие Знаменский Д.Ю., Сибиряев А.С. Интермедия, 2014 год, 177 с

2. Информационные системы и технологии управления: учебник под ред. Г.А. Титоренко Юнити-Дана, 2012 год, $591 \mathrm{c.}$

\title{
Ялмаев Р.А. \\ Определение роли местного самоуправления в системе публичной власти
}

Чеченский государственный университет им. А.А. Кадырова

(Россия, Грозный)

doi: 10.18411/trnio-12-2021-69

\section{Аннотация}

В статье анализируется место и роль местного самоуправления в единой системе публичной власти, раскрывается социально-правовое содержание российского местного самоуправления, обосновывается вывод о его дуальности. Автор приходит к выводу, что с начала 2000-х гг. наметилась явная тенденция к росту удельного веса субординационных отношений между органами государственной и муниципальной власти в ущерб отношениям равноправного взаимодействия. Эти явления свидетельствуют о том, что дальнейшая судьба местного самоуправления в нашей стране неопределенна.

Ключевые слова: местное самоуправление, местная власть, публичная власть, гражданское общество.

\section{Abstract}

The article analyzes the place and role of local self-government in the unified system of public power, reveals the socio-legal content of Russian local self-government, substantiates the conclusion about its duality. The author comes to the conclusion that since the beginning of the 2000s, there has been a clear trend towards an increase in the proportion of subordination relations between state and municipal authorities to the detriment of relations of equal interaction. These phenomena indicate that the future fate of local self-government in our country is uncertain.

Keywords: local self-government, local government, public authorities, civil society.

Сущность взаимодействия местного самоуправления с государственной властью России часто становится предметом обсуждений в литературе. В частности, обсуждаются вопросы автономности местного самоуправления, так как некоторые авторы подразумевают ее в виде полной автономии.

Так, по мнению А. Н. Костюкова, местное самоуправление можно описать как независимую функцию самоопределенных людей, в отличие от мнения о том, что местное самоуправление относится к видам автономии публичной власти. Также А. Н. Костюков отмечает, что муниципальная власть несет в себе само понятие власти народа и самоорганизации населения, которое проживает на определенных территориях, где субъектом является само население, а не различные властные структуры. [3]

Некоторые другие авторы, в частности Н.В. Постовой, придерживаются другого мнения, считая, что местное самоуправление - это, в широком смысле, вид государственной власти на местах, поскольку деятельность местного самоуправления подразумевает выполнения задач, возложенных на них государством.

Данные точки зрения представляют крайние позиции в широком спектре теорий местного самоуправления, различающиеся в отношении к месту и функциям местного управления в комплексе публичной власти, в то же время, от уяснения указанных места и 
роли зависят подходы к её организации и совершенствованию, в том числе в плане эффективности функционирования.

Теория свободной общины, с одной стороны, отражает исторический факт община как естественный, необходимый в силу природы вещей союз людей, создаётся не государством и появился раньше государства, что, по мнению ряда специалистов, делает её неприкосновенной для государственной власти [2]. С другой стороны, данная теория подвергалась критике, поскольку ею, фактически, предусматривается создание «государств в государстве» - образований, в которых не действуют государственные установления.

Коррекция теории свободной общины породила хозяйственную (общественную) теорию местного самоуправления. В её основе также лежит противопоставление государства и общины, однако выраженное менее радикальным образом предполагается, что местное самоуправление относится не к государственным, а в большей степени к хозяйственным явлениям, что означает то, что децентрализация местного самоуправления является получение населением самостоятельности лишь в вопросе ведения своими внутренними публичными интересами.

Попытки применить эту теорию на практике (в том числе в ходе земской реформы в России) натолкнулись на ряд неразрешимых в практическом отношении проблем, важнейшей из которых стала проблема невозможности точного разграничения дел общинных и дел государственных.

В результате была сформирована иная теория, известная как государственная теория самоуправления. Она состоит в том, что на местное общество (конкретнее - на выборные органы местного самоуправления) возлагается ряд задач государственного управления. Таким образом, община не только не обособляется от государства, но и напротив, призывается к службе государственным целям и интересам.

Попытки преодолеть недостатки государственной теории привели к развитию из неё дуалистической теории местного самоуправления, в каком- то смысле представляющей собой возрождение хозяйственной теории, но на новом витке теоретической мысли. Согласно данному подходу, местное самоуправление наделено самостоятельностью в решении вопросов местного значения, но при этом в решении на местном уровне государственных задач выступают как единое целое с государством. Дуализм в данном случае проявляется в том, что местное самоуправление признается и гарантируется на уровне конституционных положений как естественное право населения, но в то же время его деятельность и организация имеют подзаконный характер.

На основе данных теорий в науке муниципального права выделяются практические модели взаимодействия местного самоуправления и государства [4].

Административная модель, соответствующая государственной теории самоуправления, подразумевает встроенность муниципальных властей в систему государственной власти в качестве прямого продолжения последней на местах. Такая модель подразумевает жесткую опеку местного самоуправления со стороны органов государственной власти. Решения органов МСУ не вступают в силу без согласия, назначенного государством местного администратора. Использование данной модели говорит не о самоуправлении, а о местном управлении на самом низком уровне территориального деления государства.

Децентрализованная модель основана на теории свободной общины и подразумевает отделение муниципальной власти от государственной, т.е. её формирование исключительно местными сообществами с подчинением ей вопросов местного значения. Самостоятельность местной власти в данном случае определяется государством, но лишь в общих принципах, закрепленных в законодательстве.

Дуалистическая модель - это смешанный вариант административной и децентрализованной моделей. Органы местного самоуправления являются абсолютно автономными в рамках своих обязанностей, однако, данные обязанности определяются законодательством. 
Именно дуалистическая модель используется в России, при этом постоянно колеблясь к своим полюсам. Для нашего государства характерно местное самоуправление, располагающееся на третьем уровне власти вместе с государственной властью Российской Федерации и государственной властью субъектов Российской Федерации, что закреплено в Конституции. Из этого следует, что в настоящее время утверждение о том, что органы местного самоуправления абсолютно отчуждены от государства, не имеют под собой оснований. Одновременно, согласно статье 12 Конституции Российской Федерации, органы местного самоуправления не являются частью комплекса органов государственной власти, что означает определенное разграничение государственной власти от местного самоуправления. Из этого следует, что имеется в виду организационное разграничение государственной власти и местного самоуправления, a не разграничение в функциональном значении.

Отметим, что муниципальное образование не имеет суверенитета, которым обладает обычный в общественном понятии термин «государство». Кроме того, положение органов местного самоуправления регламентируется в Конституции Российской Федерации, а также в других законах, проблемные ситуации на местах решаются со стороны общегосударственного курса. Органы местного самоуправления также «некомпетентны в отношении своей компетенции», то есть не могут в полной мере определять круг своих полномочий [1].

Таким образом, отношения государственной и муниципальной власти в Российской Федерации хотя бы формально выстроены по дуалистической модели. Однако с начала 2000-х гг. в РФ наметилась явная тенденция к централизации публичной власти и встраиванию местного самоуправления во властную вертикаль.

Повышение степени влияния государства на деятельность местного самоуправления подразумевает под собой ослабление децентрализации, а также усиление формирования субординационного компонента взаимоотношений, на что влияет увеличение количества определенных полномочий государства, которые передаются в сферу деятельности муниципальных властей. Эти явления свидетельствуют о том, что дальнейшая судьба местного самоуправления в нашей стране неопределенна. На данный момент уже существует мнение о том, что местное самоуправление в нашей стране может стать одной из ветвей государственной власти.

Таким образом, в настоящее время как в теории, так и в практике государственного и муниципального управления все чаще возникают вопросы о нуждаемости в каких-либо новых, эффективных способах решения проблем взаимодействия органов государственной власти и органов местного самоуправления. Следует отметить как самый перспективный путь развития таких взаимоотношений в России способствование доминированию равноправного взаимодействия, снижая при этом роль субординационных отношений, которые в данный момент являются преобладающими.

$$
* * *
$$

1. Бабичев И.В. Муниципальное право: системно-структурный анализ юридических конструкций. - М.: Норма:ИНФРА-М, 2010. - 294 с.

2. Баранчиков В. А. Муниципальное право: Учеб. для студентов вузов / В.А. Баранчиков. - М: ЮНИТИ: Закон и право, 2000. $-382 \mathrm{c}$.

3. Костюков А. Н. Мировой финансовый кризис и правовые формы антикризисного поведения субъектов Федерации и муниципальных образований в России (государственно-правовой аспект) // Конституционное и муниципальное право. 2019. № 1. С. 19-23.

4. Современные проблемы организации публичной власти: монография/С.А. Авакьян, А.М. Арбузкин, И.П. Кененова и др.; рук. авт. кол. и отв. ред. С.А. Авакьян. М.: Юстицинформ, 2014. 596 с. 